https://doi.org/10.5800/GT-2017-8-3-0305

\title{
TRACKING DEEP ANCIENT CRUSTAL COMPONENTS BY XENOCRYSTIC ZIRCONS OF PALEOZOIC FELSIC IGNEOUS ROCKS FROM THE ALTAI-EAST JUNGGAR TERRANE AND ADJACENT REGIONS AND ITS TECTONIC SIGNIFICANCE
}

\author{
Jianjun Zhang1, 2, Tao Wang1, Ying Tong1, Zhaochong Zhang2, He Huang1, \\ Lei Zhang1, Lei Guo', Peng Song1, Zengqian Hou ${ }^{1}$ \\ ${ }^{1}$ Institute of Geology, Chinese Academy of Geological Sciences, Beijing, China \\ 2 State Key Laboratory of Geological Processes and Mineral Resources, China University of Geosciences, \\ Beijing 100083, China
}

The deep crustal continental components and architecture of the Central Asian Orogenic Belt have long been a matter of debate [Wang et al., 2009; Kröner et al., 2014; Xiao et al., 2015; Yang et al., 2017]. We present an integrated study of geochronological and Hf-inzircon isotopic data for xenocrystic zircons from the Paleozoic granitoid rocks and associated felsic volcanic rocks of the Chinese Altai, East Junggar and nearby regions. The aim is to trace the age spatial distribution of deep old crustal components in these key parts of the western Central Asian Orogenic Belt.
Three major zircon xenocrysts provinces are defined by their pre-magmatic age distribution and available Hf-in-zircon isotopes in our complied dataset (Figure). Province I, mainly situated in the eastern part of the central Chinese Altai, is characterized by the abundant inherited zircons with Meso-proterozoic and Paleo-proterozoic ages (1000-1600 and 1600$2500 \mathrm{Ma}$ ), and variable $\varepsilon_{\mathrm{Hf}(\mathrm{t})}$ values ranging from -15 to +7 with ancient $\mathrm{Hf}$ crustal model ages ( $\mathrm{T}_{\mathrm{DMC}}$ ) ranging from 1.5 to $2.9 \mathrm{Ga}$. A few scattered parts of province I are scattered situated in the East Junggar (individual 


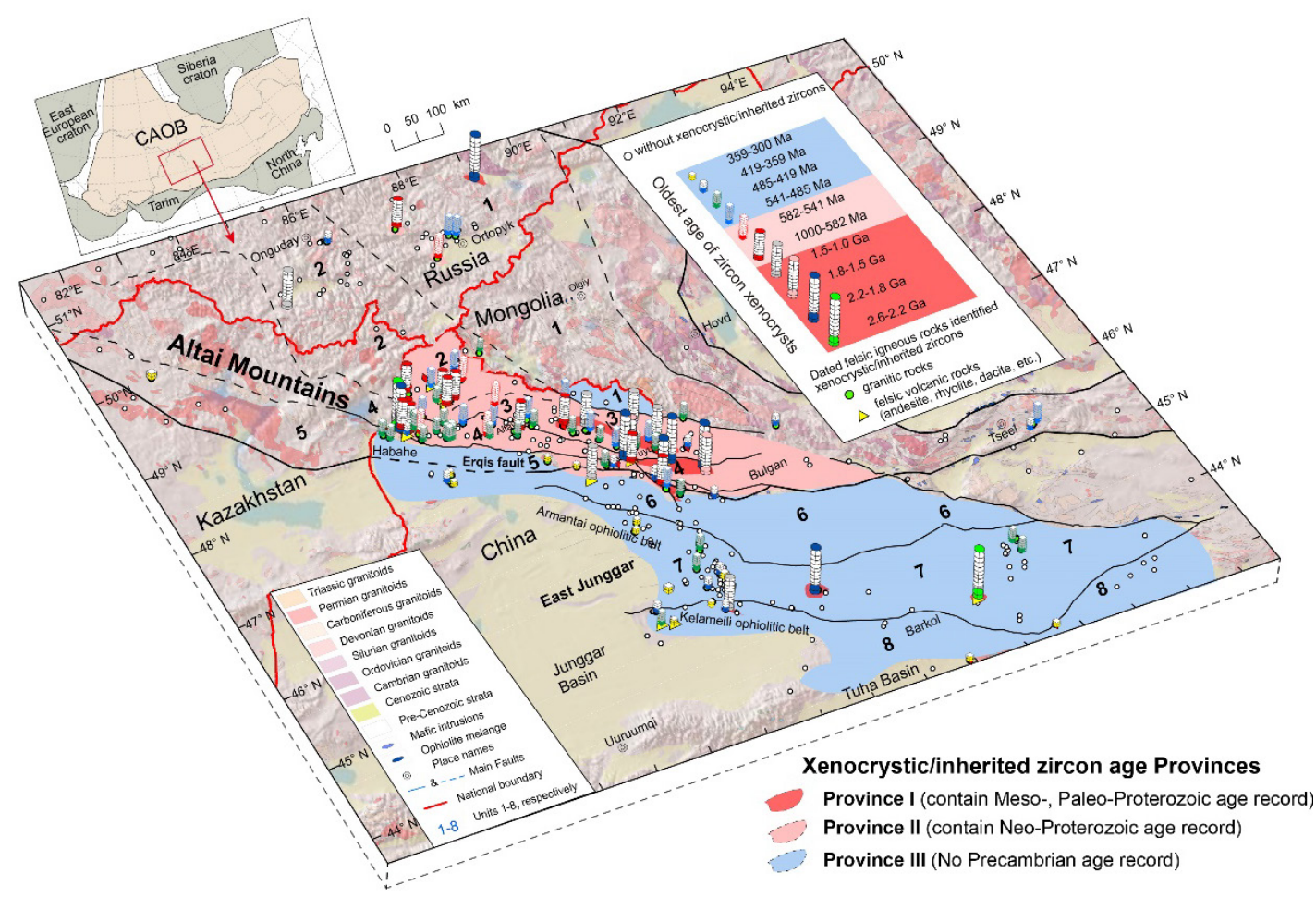

The inferred framework of old zircon xenocryst provinces, based on the variations in spatial characteristics of age and Hf isotopic compositions $\left(t_{D M C}\right)$ of xenocrystic zircons within Paleozoic felsic igneous rocks. These provinces reveal the architecture and distribution of deep ancient continental components in the Altai-East Junggar terrane and adjacent regions (after [Zhang et al., 2017]).

areas, e.g., Taheir and Shuangchagou). Province II, situated mostly in the central Chinese Altai, is characterized by abundant xenocrystic zircons with Neo-Proterozoic ages (542-1000 Ma), $\varepsilon_{\mathrm{Hf}(\mathrm{t})}$ values ranging from -6.8 to +8.1 and correspond $\mathrm{Hf}$ crustal model ages of $\sim 1.0$ to $1.3 \mathrm{Ga}$. Province III contains abundant Phanerozoic $(<541 \mathrm{Ma})$ xenocrystic zircons that show highly positive $\varepsilon_{\mathrm{Hf}(\mathrm{t})}$ values ranging from +5 to +16 and the youngest $\mathrm{Hf}$ crustal model ages $(0.40-0.95 \mathrm{Ga})$. The main part of Province III occupies most areas of the East Junggar and the southernmost and northern parts of the Chinese Altai.

Identification of the ancient (pre-Neoproterozoic) Hf crustal model ages in the eastern part of the central
Chinese Altai (Province I) supports the suggestions that ancient concealed crustal components exist in the Chinese Altai. In contrast, Province III in the East Junggar predominantly displays young model ages, which indicate that it is mainly composed of juvenile components and likely a typical accretionary belt. Besides, a few small areas with ancient model ages are recognized in the East Junggar, providing evidence for the local existence of Precambrian crust or micro-blocks within the accretionary belt. The zircon xenocrysts provinces consist with the $\mathrm{Nd}$ isotopic province and provide further evidence for the ancient and juvenile compositions in deep.

\section{REFERENCES}

Kröner A., Kovach V., Belousova E., Hegner E., Armstrong R., Dolgopolova A., Seltmann R., Alexeiev D.V., Hoffmann J.E., Wong J., Sun M., Cai K., Wang T., Tong Y., Wilde S.A., Degtyarev K.E., Rytsk E., 2014. Reassessment of continental growth during the accretionary history of the Central Asian Orogenic Belt. Gondwana Research 25 (1), 103-125. https://doi.org/10.1016/j.gr.2012.12.023.

Wang T., Jahn B.-M., Kovach V.P., Tong Y., Hong D.-W., Han B.-F., 2009. Nd-Sr isotopic mapping of the Chinese Altai and implications for continental growth in the Central Asian Orogenic Belt. Lithos 110 (1-4), 359-372. https:// doi.org/10.1016/j.lithos.2009.02.001.

Xiao W.J., Windley B., Sun S., Li J.L., Huang B.C., Han C.M., Yuan C., Sun M., Chen H.L., 2015. A tale of amalgamation of three Permo-Triassic collage systems in Central Asia: oroclines, sutures, and terminal accretion. Annual Review of Earth and Planetary Sciences 43, 477-507. https://doi.org/10.1146/annurev-earth-060614-105254. 
Yang Q.D., Wang T., Guo L., Tong Y., Zhang L., Zhang J.J., Hou Z.Q., 2017. Nd isotopic variation of Paleozoic-Mesozoic granitoids from the Da Hinggan mountains and adjacent areas, NE Asia: implications for the architecture and growth of continental crust. Lithos 272-273, 164-184. https://doi.org/10.1016/j.lithos.2016.11.015.

Zhang J.J., Wang T., Tong Y., Zhang Z.C., Song P., Zhang L., Huang H., Guo L., Hou Z.Q., 2017. Tracking deep ancient crustal components by xenocrystic/inherited zircons of Palaeozoic felsic igneous rocks from the Altai-East Junggar terrane and adjacent regions, western Central Asian Orogenic Belt and its tectonic significance. International Geology Review (in press). http://dx.doi.org/10.1080/00206814.2017.1308841. 